\title{
INNOVATIVE APPROACHES TO GREENING ENTREPRENEURSHIP
}

\author{
Yuliia Horiashchenko'
}

\begin{abstract}
The purpose of this study is to analyze the state of implementation of modern eco-innovations and assess their impact on improving the competitiveness of enterprises. Methodology. The main research methods were analysis and synthesis in the study of economic processes that accompanied innovation in enterprises; statistical analysis in the study of the dynamics of waste by type of economic activity and in households; comparative analysis in assessing the world practice of eco-innovation in production; specific and abstract comparative characteristics - in presenting the results, providing conclusions and suggestions for research. Results. Interactive links between innovation and greening are identified. It is emphasized that eco-innovation means a special form of innovation aimed at significantly improving the environment. A critical analysis of the regulatory framework governing sustainable development in Ukraine is made. A statistical assessment of the waste generation process by regions of Ukraine in 2019, including hazard classes I-III, is provided. A secondary statistical observation was conducted, based on the results of which it can be concluded that today three out of twenty people in the world prefer ecological products. It is stated that modern enterprises face a large number of challenges, among which the leading place is occupied by environmental protection and digitalization. The importance of digital, blue and green entrepreneurship (circular business) in Ukraine and the world is proved. The competitive advantages of "digital", "green" ("blue") business are obvious: environmental friendliness today is a global trend, and digitalization is the content and benchmark of entrepreneurship; there is currently little competition in green and blue business; their products are in growing demand among consumers; in these types of business there are endless opportunities for the manifestation of creative innovative ideas; these types of business are supported by the public, the state and the world community; eco-innovation can significantly reduce business costs, create conditions for investment and access to foreign markets. Practical implications. These practical recommendations can be applied not only in the Ukrainian business space, but also in the business of countries that have chosen sustainable development. Value/originality. The conducted research can become a theoretical basis for practitioners who aim to provide competitive advantages by greening activities. It is established that the competitive advantages of business today are formed under the influence of globalization processes, digitalization, increasing capital mobility, informatization, and most importantly - improving environmental living standards.
\end{abstract}

Key words: eco-innovations, greening entrepreneurship, wastes generation, sustainable development, environment, digitalization.

JEL Classification: M21, 013, 014, O31, 044

\section{Introduction}

Modern enterprises face a large number of challenges, among which the preservation of the environment occupies a significant place. However, the problem is exacerbated by an increase in overall consumption and production, which increases the burden on the environment. At the same time, managers and business owners are aware that greening is an important factor in sustainable innovation and can provide

\footnotetext{
Corresponding author

${ }^{1}$ University of Customs and Finance, Ukraine.

E-mail: julia.goryaschenko@gmail.com

ORCID: https://orcid.org/0000-0001-7020-1412
}

a significant advantage over competitors. In addition, a large number of world examples show that the development of an innovative vision and strategy in the field of greening has a positive effect on both organizational identity and creativity of enterprises. Today, the green economy is not just about reducing risks to the environment and the scarcity of environmental resources. Nowadays, greening is a synergy of the triads "economy-ecology-society" (sustainable 
development) and "science-education-innovation" (knowledge triangle). For more than 20 years, the category "eco-innovation" has meant three types of changes on the path to sustainable development: technological, social and institutional innovation (Klaus Rennings, 2000). Eco-innovation means all forms of innovation aimed at significantly improving the environment. They can include new production processes, goods or services, as well as new methods of management and business, the use or implementation of which prevents or significantly reduces risks to the environment in terms of pollution or any other negative impact on nature, economy and humans (Nalyvaiko, 2017). According to open sources, the level of solid waste recycling in Ukraine ranges from 3 to $8 \%$, while in the European Union it is up to $60 \%$. At the same time, more than $90 \%$ of solid waste is sent to landfills and unauthorized landfills. According to official estimates, about 6,700 landfills and dumps occupy 10,000 hectares of land in Ukraine, although unofficial figures may be even higher (IFC, 2020).

\section{Legal regulation of eco-innovations in Ukraine}

Ukraine is a party to more than 20 international conventions and bilateral agreements related to environmental protection. Ukraine's international commitments on the environment, the use of natural resources and environmental security stem from the provisions already ratified and under review of conventions and agreements. Ukraine's fulfillment of its obligations under these multilateral agreements requires bringing domestic legislation in line with international law and taking into account existing international practice when drafting new legislation. The most important documents governing environmental issues in Ukraine are Constitution of Ukraine, the Laws (On Environmental Protection, On Waste), Subsoil Code, Budget Code, Land Code, Forest Code, Water Code, the Laws (On the Basic Principles (Strategy) of the State Environmental Policy of Ukraine, On Ensuring the Sanitary and Epidemic Well-Being of the Population, On Pesticides and Agrochemicals, On Radioactive Waste Management, On Air Protection, On the Nature Reserve Fund of Ukraine, On Amendments to Article 17 of the Law of Ukraine "On Environmental Impact Assessment to Prevent the Occurrence and Spread of Coronavirus Disease (COVID-19)", On Environmental Impact Assessment, On Strategic Environmental Assessment, On Access to Public Information, On Citizens' Appeals, On Civil Service). Let us dwell in more detail on the main documents. The Law of Ukraine "On Waste" with amendments and additions and the Program of Solid Waste Management are aimed at the development of processing technologies and minimization of waste generation. There is no term "municipal solid waste" in Ukrainian legislation; instead, the term "solid household waste" is used. In fact, solid household waste is understood as all waste generated in the territory of cities and settlements, including waste from the commercial sector, similar in composition to household waste. Under the new rules for solid waste management, local authorities and citizens are obliged to organize separate waste collection. The Cabinet of Ministers of Ukraine has decided to introduce a compensation mechanism for the disposal of packaging and packaging waste with defined targets. Today in Ukraine, the environmental label (ecolabel) is becoming widespread.

Collection of environmental tax in Ukraine is regulated by a section of the Tax Code:

- for emissions into the air of pollutants by stationary sources of pollution, discharges of pollutants into water bodies, placement during the reporting quarter of waste in specially designated places or facilities - at the location of stationary sources, specially designated places or objects;

- for the generation of radioactive waste and temporary storage of radioactive waste beyond the period established by the special conditions of the license - at the location of the taxpayer on the tax register with the supervisory authorities.

Ukraine's long-term goal is to achieve the EU standards for waste recycling, which are already partially mandatory under the EU-Ukraine Association Agreement. This will require the following steps:

- ensuring environmentally safe management of solid waste (in particular, compliance with the requirements for landfills);

- introduction in practice of the hierarchy of solid waste management, according to which preference is given to preventing their generation and processing, rather than incineration and disposal of waste; 
- full application of the "polluter pays" principle;

- gradual achievement of targets for separate waste collection and recycling of the most important fractions to be reused;

- achieving indicators of separate waste collection and recycling at the level of 60 and $50 \%$ of the total amount of solid waste, respectively (one of the most important targets);

- ensuring the recycling of packaging waste at the level of 55\% in accordance with the EU Directive on packaging materials No. 94/62/EC and the recycling of construction waste at the level of $70 \%$ in accordance with Directive No. 2008/98 /EC. Unfortunately, the envisaged legislative measures are not always fully implemented in practice. In order to create an effective waste management system in Ukraine, it is necessary to consider and adapt best international practices, for example, those European countries that have already harmonized their legal framework with EU legislation and brought it in line with applicable directives (IFC, 2020).

\section{Innovative approaches to greening in different sectors of the economy}

According to the State Statistics Service of Ukraine, up to 500 million tons of waste are generated annually in the country, including primary production waste $(76 \%)$, secondary production waste (about $18 \%$ ), agricultural waste (about 2\%) and municipal solid waste (about 2\%). According to Eurostat estimates, the total amount of waste in the EU member states averaged 6 tons per capita, while in Ukraine in 2019 this figure was 10.5 tons per capita. At the same time, it should be noted that in Ukraine the share of industrial waste accounts for up to $94 \%$ of total waste (State Statistics Service of Ukraine, 2021).

According to the data presented in Figure 1, it is possible to state a tendency towards an increase in waste by economic activity and in households per capita over the past 25 years. At the same time, in 2019 the indicator rose sharply and reached its peak. This should alert the government and the public. According to preliminary estimates, given the difficult economic situation due to the effects of the COVID-19 pandemic, the situation may worsen further.

The indicator of total generated waste includes:

- agricultural, forestry and fishing waste;

- mining and quarrying waste;

- manufacturing waste;

- electricity, gas, steam and air conditioning supply waste;

- construction waste;

- other economic activities waste;

- the amount of waste collected, received from households waste.

The minimum value of the Waste generation in 2019, by region was recorded in Zakarpattia (153.1 thsd t), maximum - in Dnipropetrovsk region (252234.5 thsd $t$ ). However, in the context of Wastes generation of hazard classes I-III in 2019, Donetsk and Sumy regions are in the lead (State Statistics Service of Ukraine). The amount of environmental taxes paid by enterprises, organizations, institutions in 2019 amounted to

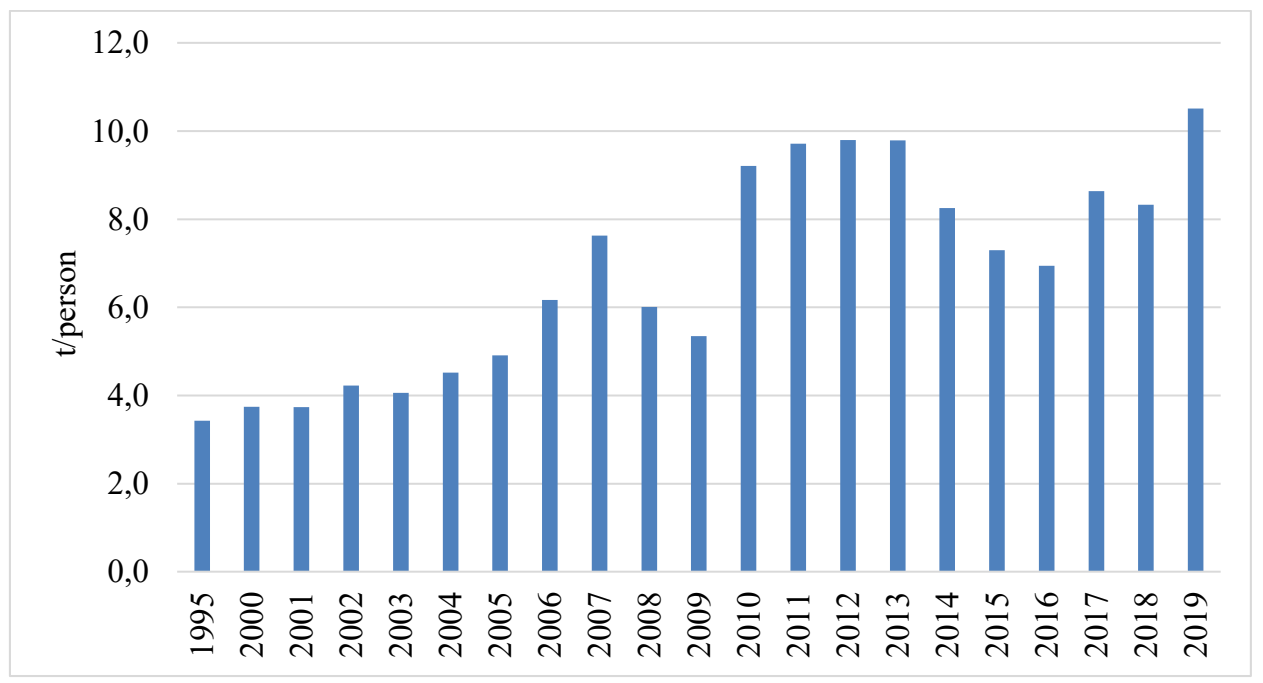

Figure 1. Dynamics of waste by all types of economic activity and in households per capita in Ukraine 
5013 mln UAH, which was more than the previous period by $61 \mathrm{mln}$ UAH.

The waste situation in the EU has improved somewhat due to the tightening of legislation and enforcement. The commercialization of waste recycling and the emergence of new technologies for their management have in turn improved recycling. The main problem facing the European recycling sector is the constant increase in waste. Among the tasks is to turn old car tires into reusable "eco-rubber", as well as a project to more efficiently recycle aluminum. The first initiative involves the annual reuse of 190 tons of rubber and plastic from recycled tires using new technologies. This technique generates copolymers for use in thermoplastic rubber. The project is generally focused on the construction and automotive markets. Innovative projects in different sectors that aim to prevent or reduce environmental impact, i.e. that contribute to the optimal use of resources, differ. For example, in the field of recycling:

- improvement of waste sorting processes, separately from construction, industry, household, etc;

- ecological design and production of high-quality consumer goods, innovative processing processes;

- business innovations that strengthen the competitiveness of recycling industries.

In the field of construction:

- innovative building materials that reduce the impact on the environment and support the rational use of natural resources;

- innovative sorting, reuse and processing of construction waste and demolition of construction sites;

- innovative water systems, including water saving, natural water reuse, rainwater collection and reuse, green roofs.

In the food sector:

- innovative products, including packaging methods and materials that reduce environmental impact and maximize the use of raw materials in the food industry (Global Ecolabeling Network, 2021);

- cleaner and more efficient processing of food and beverages in order to reduce waste and increase the processing and recovery of materials;

- improving the efficiency of water use in various processes, which will reduce the use of water in the food and beverage supply chain.

In the field of environmental business and "smart" procurement:
- goods and services that comply with the principles of integrated product policy and life cycle approach, as well as in accordance with sustainable consumption and production and sustainable industrial policy;

- introduction and promotion of ecological criteria for decisions of enterprises;

- innovative approaches, which will include increasing the resource and energy efficiency of enterprises.

\section{Examples of application of eco-innovations in the world}

As known, the "green economy" is based on practical and theoretical knowledge related to climate change and environmental policy development, "blue economy" is becoming an alternative paradigm of development that combines the economic use of the oceans with environmental sustainability (Green, Blue \& Digital Economy Journal, 2021). Naturally, the change of strategies and models of business development is currently taking place under the influence of a third force - the digital economy. In the latter, business is increasingly taking electronic form (e-business, e-commerce, digital production, ICT).

Here are some examples of eco-goods and services from the European countries: bio-dyes for the textile industry, biodegradable footwear, ecobrand and milk bottles from recycled paper and plastic, innovative processes for the manufacture of ceramics, leather and textiles, which save many resources, etc. Among the well-known projects is the Parilas project (2010-2012) using builtin laser identification, which demonstrates the next generation of high-performance aluminum processing. One Parilas system installed can replace 10,000 tons of new aluminum per year. Another composite concrete project, EcoWall, supports the green building initiative to reduce environmental impact by producing modular composite concrete panels that save on construction costs and improve thermal insulation, use industrial waste and recycle them to make panels. The Ecobionet project (2010-2013 and beyond) offers the production of various types of biodegradable nets using a more complex and reliable extrusion melt spinning process. Grids must have good physical and mechanical properties, be completely biodegradable and be competitive with other solutions on the market. Packaging nets can 
be tested for use as packaging for agricultural products. The idea was to industrialize four biodegradable packaging nets and test them for strength and cost-effectiveness.

In today's conditions of development, entrepreneurs make significant efforts to make innovative products, which are emerging in high-tech industries and services, to become competitive and environmental. Instead, the total share of enterprises that implemented innovations in Ukraine decreased from $15.2 \%$ in 2015 to $13.8 \%$ in 2019.

The results of the EY Future Consumer Index study on the distribution of consumers according to their main priorities (sample - 14.5 thousand people (20 countries of the world), 2020) (Balis Janet, 2020) indicate that the main characteristic value for consumers: Availability (32\%), Health (25\%) and Planet (Environmental friendliness of the product) (16\%). Therefore, business leaders and owners need to focus on these assessments and change the business model as needed.

\section{Conclusions}

1. Eco-innovation means all forms of innovation aimed at significantly improving the environment. Eco-innovation may include new production processes, goods or services, as well as new methods of management and doing business, the use or implementation of which prevents or significantly reduces risks to the environment, in terms of pollution or any other negative impact of resource use throughout life cycle of the relevant field of activity.
2. The analysis revealed a tendency to increase the amount of waste by type of economic activity and in households per capita in Ukraine during the years of independence.

3. From the standpoint of the complementarity of the triads "ecology-economy-society" (sustainable development) and "science-education-innovation" (knowledge triangle), business today is expected not just innovative products and services, but increasingly - eco-innovation aimed at significant improvement of the environment, minimal negative impact on society and the economy.

4. Today, the competitive advantages of business are formed under the influence of globalization processes, digitalization, increasing the mobility of capital, informatization, and raising environmental living standards. The competitive advantages of "digital", "green" and "blue" business are obvious: firstly, environmental friendliness today is a global trend, and digitalization is the content and benchmark of entrepreneurship; secondly, there is currently little competition in green and blue business; thirdly, their products are in growing demand among consumers; fourthly, in these types of business there are endless opportunities for the manifestation of creative innovative ideas; fifthly, these types of business are supported by the public, the state and the world community; sixth, eco-innovation can significantly reduce business costs, create conditions for investment and access to foreign markets. Therefore, the importance of digital, blue and green entrepreneurship (circular (inexhaustible) business) cannot be overestimated.

\section{References:}

Balis, Janet (2021). 10 Truths About Marketing After the Pandemic. Available at: https://hbr.org/ 2021/03/10-truths-about-marketing-after-the-pandemic (accessed 08 April 2021).

Boosting green business (2011). Available at: https://ec.europa.eu/environment/eco-innovation/files/ docs/publi/eaci_brochure_eco_innovation_a4_lr_en.pdf (accessed 03 April 2021).

Eco-innovation. $\bar{W}$ hen business meets the environment. Available at: https://ec.europa.eu/environment/ eco-innovation/projects/ (accessed 03 April 2021).

Global Ekolabelling Network (GEN). Available at: https://globalecolabelling.net/ (accessed 04 April 2021).

Green, Blue \& Digital Economy Journal. Available at: http://baltijapublishing.lv/index.php/gbdej (accessed 11 April 2021).

Horbach, Jens \& Reif, Christiane (2018). New Developments in Eco-Innovation Research, Springer: 310. IFC. Available at: https://www.ifc.org/wps/wcm/connect (accessed 11 April 2021).

Nalyvaiko, N. (2017). Obiektyvna potreba ekolohizatsii diialnosti derevoobrobnykh pidpryiemstv [The objective need to green the activities of woodworking enterprises]. Naukovyi visnyk NLTU Ukrainy, vol. 27(2), pp. 24-28. (in Ukrainian)

Parilas. Available at: https://www.parilas.eu/ (accessed 09 April 2021).

Rennings, Klaus (2000). Redefining innovation - eco-innovation research and the contribution from ecological economics. Ecological Economics, vol. 32(2), pp. 319-332.

State Statistics Service of Ukraine. Available at: http://www.ukrstat.gov.ua/ (accessed 08 April 2021). 